\title{
太田川感潮部の非定常乱流 \\ NONSTATIONARY TURBULENCE IN THE OTA RIVER ESTUARY
}

\author{
川西 澄*・余越正一郎** \\ By Kiyosi KAWANISI and Shōitirō YOKOSI
}

\begin{abstract}
Simultaneous measurements of turbulent velocities, salinities and turbidity were made during two tidal cycles in the Ota River estuary. The Reynolds stresses measured at height of $0.4 \mathrm{~m}-1.2 \mathrm{~m}$ above the river bed were consistently higher in decelerating flow than in accelerating flow. On the other hand, vertical sediment flux in accelerating flow was greater than in decelerating flow. The flux Richardson number estimated at height of $0.8 \mathrm{~m}$ above the river bed increased in ebb tide. The integral length scale of vertical turbulent velocity was sensitive to the magnitude of the flux Richardson number. The large-scale turbulence transported more sediment than the small-scale turbulence.

Keywords : tidal river, turbulence, field observations, suspended sediment
\end{abstract}

\section{1.はじめに}

河川感潮部の流れは, 潮汐や, 河川水と海水の密度差 などの影響を受けて非定常で複雑であるが, その乱流構 造を理解することは, 洪水の疎通や河川水の利用（選択 取水), 航路保持, 水質污濁等の多様な問題の解決につ ながり，工学上重要である，それにもかかわらず，研究 が困難なため, 感潮部における乱流構造に関する正確な 知識は現在のところほとんどない.

感潮河川乱流の特徴は, 潮汐とともに時間的, 空間的 にその構造が大きく変化することである．乱流構造に影 響する要因としては，(1) 流向・平均流速が変化する往 復流であること，(2) 水深が変化すること（特に瀬戸内 海沿岸では変化が大きい), (3) 海水と河川水の塩分濃度 差によって生ずる密度流や成層化，(4)流れとともに河 床形状が変化する移動床流れであること，などが挙げら れ, 河川感潮部ではこれらの要因が乱流構造と複雑に作 用し合っている.

本論文は, 潮汐に伴い時々刻々と変化する河川感潮部 の非定常乱流の実態を現地観測から把握することを目的

* 正会員 工博 広島大学助手 工学部四類 (建設系) ( ₹724 東広島市西条町下見)

** 正会員 工博 広島大学教授 工学部四類 (建設系) (同上)
とする．潮差が大きく非定常性の強い感潮河川として， 太田川放水路を観測対象として選び，日潮不等を考慮し て潮汐 2 周期間連続した流速亡塩分濃度, 濁度の同時測 定を行った.

\section{2. 観 測 概 要}

太田川は現在, 広島デルタの北部で 6 つの河川に分か れて広島湾に注いでいるが，太田川放水路はこのうち， 最西部に位置する河川で, その平面形状, 断面形状とも 比較的単純で浮遊物も少なく, 下流部では干潮時にも十 分な水深があり，観測には適している．放水路河口から 市内派川との分派口までの長さは約 $9 \mathrm{~km}$, 河口部の河幅 は $425 \mathrm{~m}$, 分派口の河幅は $287 \mathrm{~m}$ であり, 河口から上流 約 $5 \mathrm{~km}$ 区間の河道はほぼ直線である.分派口には，放 水路側と市内派川側にそれぞれ，祇園水門と大芝水門が 設けられている. 平常時, 祇園水門の開度は $10 \mathrm{~cm}$, 大 芝水門は全開にしてあり，太田川流量の大部分は維持流 量として，市内派川へ流されている。このため, 祇園水 門付近の水深は, 大潮の満潮時 $2 \mathrm{~m}$ 程度であるが，干 潮時には河床の大部分が露出する. したがって, 放水路 に流入する河川水はわずかで，放水路内は潮汐流が支配 的である. また，大潮時の潮差はかなり大きく，観測地 点で $4 \mathrm{~m}$ 近くある. Fig. 1 に観測地点（○で示す）とそ 

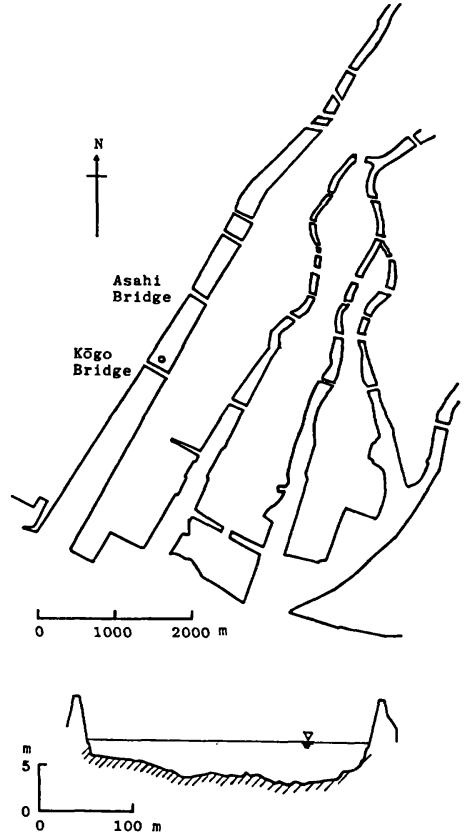

Fig. 1 Sketch map of Hiroshima delta and cross section of the measuring point $(\mathrm{O})$.

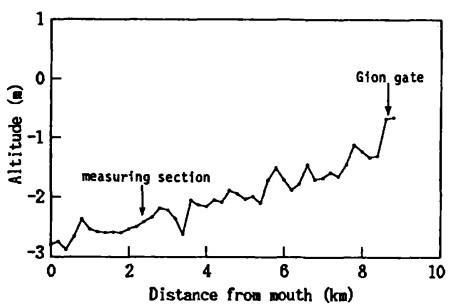

Fig. 2 Longitudinal profile of the Ota deversion channel bed.

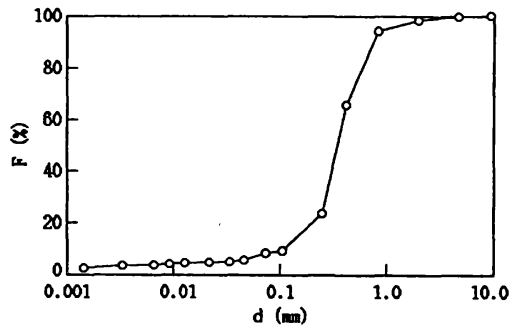

Fig. 3 Grain size distribution of sediment (1986.12).

の横断形状を, Fig. 2 に平均河床縦断図を示す. 観測地 点は河口から約 $2.5 \mathrm{~km}$ 上流の河川中央部に位置し, 河 幅は約 $300 \mathrm{~m}$ である．河床は右岸側が低く，航路になっ ている. 観測地点における河床材料の粒度分布をFig. 3 に示す. 中央粒径は $0.36 \mathrm{~mm}$, 均等係数は 2.4 である. ただし，1986 年 12 月の干潮時に採取した土砂から求め たものである。

観測はすべて, 非定常性が最も強く現われる大潮時に
行った. 流速測定には 2 成分電磁流速計 (時定数 0.1 秒) を使用し, 塩分濃度は温度補償回路つきの導電率計を, 浮遊砂泥濃度は散乱光式濁度計（時定数 0.5 秒）を使っ て測定した. 各測器の受感部は外径 $25 \mathrm{~mm}$ のアルミ管 フレームに取り付け，重りで河床に固定した２成分電 磁流速計は, 主流方向と鉛直方向の流速 $(U, W)$ を测 定するように取り付け, 流向は上げ潮, 鉛直上向きを正 とした.なお, 電磁流速計どうしの干渉を防ぐため, 各 流速計間で同期をとって交流磁界を発生させている，導 電率計の受感部は電磁流速計との相互干渉を防ぐため, 横方向に $5 \mathrm{~cm}$ 程度離して設置した. また, 流速計の傾 斜による鉛直乱流フラックスの测定䛊差を除くため, 電 磁流速計のセンサーには容量式傾斜計を取り付け, その 出力を流速とともにデータレコーダーに同時記録してお き, $\mathrm{AD}$ 変換後の流速データに角度補正を施した。なお, 水深 $D$ はフレームに固定した圧力変換器を使って連続 測定した.

\section{3. 観 測 結 果}

\section{（1）潮汐に伴う平均流速と平均塩分濃度の非定常挙 動}

Fig. 5 に河床上 $0.4 \mathrm{~m}$ 間隔で設けた 4 測点における平 均流速之水深の経時変化を（ $z$ は河床からの高さ）,

Fig. 6 に平均流速の鉛直分布の経時変化を示す. 観測は 1985 年 11 月 25〜26日に行った. 流速計と導電率計の 鉛直配置をFig. 4 に示す. Fig. 6 中の英字は, Fig. 5 中の 英字に対応しており, 矢印は時間の経過方向を示してい る. また, Fig. 6 中の縦軸は相対高さ $z / D$ である.なお, 一部の干潮では, 最上部の測点は水上に露出したため除 いてある. Fig. 5 をみる, 水深が大きく変化するため に, 平均流速の経時変化は正弦曲線よりかなりひずみ, 水深の小さな干潮の前後で流速が大きくなっている．ま た，底層では, 下げ潮より上げ潮の方が最大流速は大き く, 潮汐 1 周期平均の流速は陸向きで, 重力循環流が生 じていることがわかる.

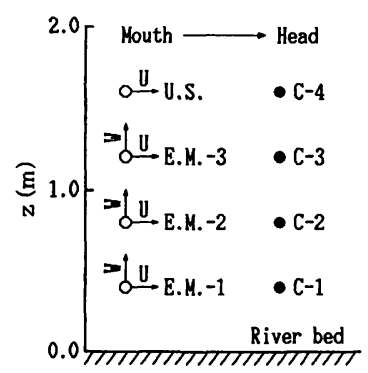

Fig. 4 Vertical arrangement of sensors.

(E. M. -1 E. M. -3 : Electromagnetic, U. S. : Ultrasonic, $\mathrm{C}:$ Conductivity) 


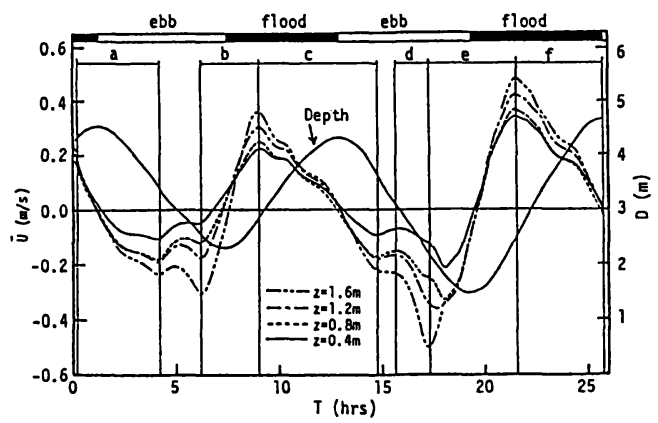

Fig. 5 Temporal variations of depth and mean longitudinal velocity at four heights $(\boldsymbol{z})$ above the river bed (1985.11).

次に, Fig. 6 に示す平均流速の鉛直分布をみてみると, 上げ潮と下げ潮ではかなり様子が異なっていることがわ かる．下げ潮は上げ潮に比べて，上層の流速が大きく下 層の流速が小さい直線的な分布となっている.たとえば, Nicholas ら ${ }^{1)}$ 同様な結果を得ており，このような流速 分布を生じさせる原因としては，安定成層化と主流方向 の密度勾配の存在が考えられる.つまり, 式 (1) で示 すように，主流方向の密度勾配に起因する負の圧力勾配 が深いところほど大きいためと（３）で述べるように， 下げ潮時に安定成層度が強くなるため，Fig.6のような 流速分布となる. 式（1）において $z$ と $H$ はそれぞれ 基準面からの高さと水位である.

$$
\frac{\partial P}{\partial x}=\rho g \frac{\partial H}{\partial x}+g \int_{z}^{H} \frac{\partial \rho}{\partial x} d z
$$

Fig. 6 をみると, 下げ潮から上げ潮への転流時, 底層が 上層より先に流向が逆転している．往復流では転流時, 上層より底層の方が位相が進むが2)，観測地点では主流 方向の密度勾配のために,下げ潮から上げ潮への転流時, この位相差が助長され，上げ潮から下げ潮への転流時に は, 逆に位相差が抑えられていると考えられる.つまり， 式（1）の右辺第 2 項で表わされる主流方向密度勾配に 起因する負の圧力勾配（下流から上流に向かう流れを発 生させる）が深いところほど大きいために，上層に比べ て下層は，満潮時には流向の反転が遅れ，干潮時には逆 に流向の反転が早くなる.

Fig. 7 は 1984 年 9 月 11 12 日における塩分濃度分布 の経時変化を示したもので, 河床から $1 \mathrm{~m}$ おきに設け た 5 つの測点から得られたものである. 縦軸は水面を 1.0 とした河床からの無次元高さで, 横軸は経過時間で ある. 干潮の前後で等濃度線が密になっており, 濃度変 化が急であることがわかる，また，下げ潮時，水面付近 から濃度が低下しているのに対し，上げ潮の濃度増加時 には，等濃度線はほぼ鉛直で，濃度が鉛直方向にほとん
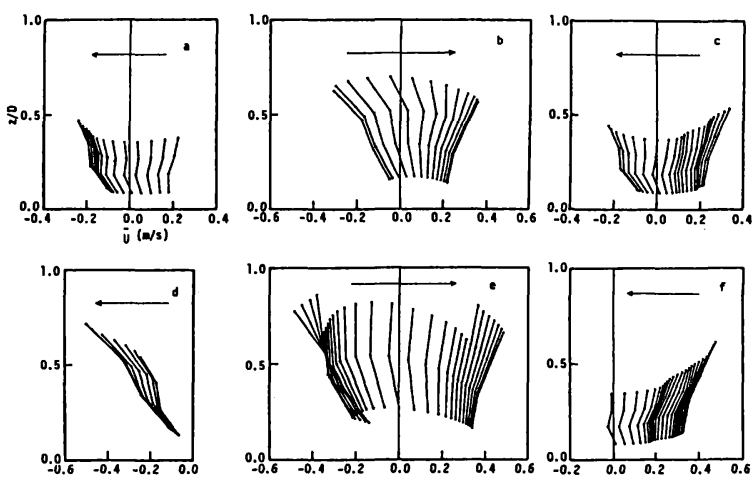

Fig. 6 Temporal variations of velocity profile. Alphabets in the Fig. 6 corresponds to that in Fig. 5. Arrows indicate the direction of time (1985.11).

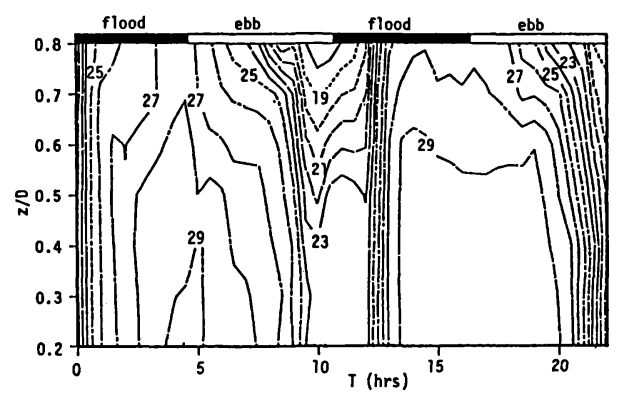

Fig. 7 Contour map of salinity variation (\%o) (1984.9).

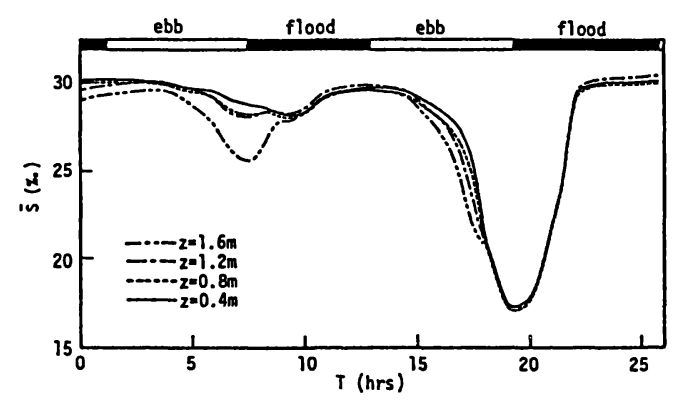

Fig. 8 Temporal variations of mean salinity at four heights $(\boldsymbol{z})$ of above the river bed (1985.11).

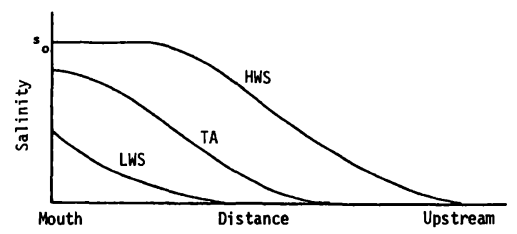

Fig. 9 Typical salinity distributions at high water slack (HWS), low water slack (LWS) and time average salinity over one tidal cycle (TA) (from Harleman et al. $\left.{ }^{3)}\right)$. 
ど一様になっていることがわかる.Fig. 8 に示す 1985 年 11 月 25 26 日の 4 測点における平均塩分濃度の経時 変化もFig. 7 上同様に，濃度の経時変化は正弦的ではな く, 満潮付近では変化が小さく, 干潮の前後で急激に変 化している．このような塩分濃度変化を示す理由は，主 流方向濃度分布の変化 (Fig. 9 $^{3)}$ ) から説明される.す なわち，(満潮時にみられるような) 河口付近で濃度勾 配が緩やかで上流では急な主流方向濃度分布が，潮の干 満に伴って下流上流に移動すると考えると，測点が濃度 勾配の緩やかな領域にある満潮付近では濃度の時間的変 化は少なく, 測点が濃度勾配の急な領域にある干潮付近 では濃度の時間的変化は大きくなる.

日潮不等のため, 1 回目と 2 回目の干潮時における塩 分濃度は大きく異なり，濃度低下が小さいときの方が鈶 直方向の濃度差が大きくなっている。

上げ潮時，鉛直方向にほとんど濃度差がない状態で河 口から海水が平均流で運ばれるため，平均流速の大きな 上層の方が, 下層より塩分濃度が高くなる可能性がある. Fig. 8 をみると，上げ潮時，わずかながら鉛直方向の濃 度勾配が逆転しているのが認められる。

\section{（2）潮汐位相とレイノルズ応力，浮遊砂泥乱流フ ラックス}

河川感潮部では平均流速が大きく変化するために, 乱 れの寸法が同一でも,その通過時間は変化する.したがっ て，たとえ乱流構造自体に変化がなくても周波数スペク トルは変化するし, 乱れの各種統計量を求める際の平均 時間長も平均流速の大きさに応じて変化させなければな らない（平均流速が小さいほど乱れの通過時間は長くな るから, 乱れの統計量はそれだけ長く平均して求める必 要がある). 乱れの移流速度が平均流速に等しいとおく Taylor の仮説をせん断流に適用するには問題もある が4)，平均流速と乱れの移流速度が大きく異なることは ないと考え，移流速度を各測点における局所平均流速を 平均したもの $\left(\bar{U}_{a}\right)$ に等しいと仮定し，読取り時間間 隔 $\Delta t=0.32$ 秒の時系列デー夕を, 移流距離間隔 $\Delta x=$ $\left|\bar{U}_{a}\right| \Delta t$ の移流距離系列デー夕に変換して解析した ${ }^{5)}$. ただし, $\left|\bar{U}_{a}\right|<0.1 \mathrm{~m} / \mathrm{s}$ では変換していない.

次に, 河川感潮部は平均流速が変化する非定常乱流場 であるから, 平均之乱れ成分の分離が問題となる. 野外 観測では，対象とする現象に完全な再現性がないから， 往復流の実験のようにアンサンブル平均により平均成分 を求めることはできない，そこで，本論文では，鉛直方 向の乱流輸送に主として寄与する乱れを解析の対象と し, 移流距離長 $L_{c}=131 \mathrm{~m}$ (時間長 328 秒 $\sim 1311$ 秒, デー夕数 4096 ) のデータからトレンドを除去したもの を, 流速と塩分濃度そして濁度の乱れ成分 $(u, w, s, c)$ とみなした。 トレンドの除去には 3 次多項式を使用し，

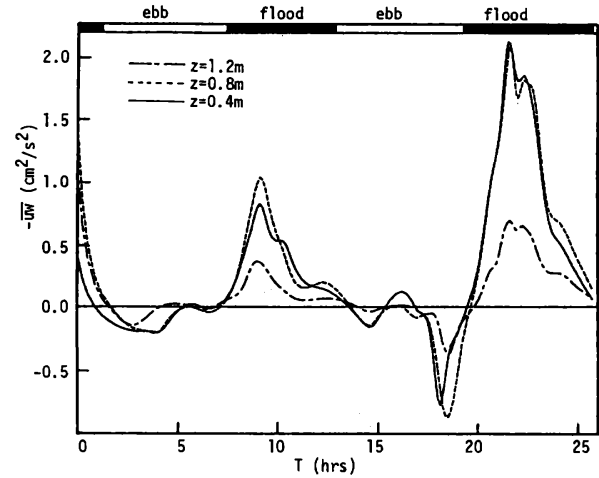

Fig. 10 Temporal variations of the Reynolds stress at three heights $(z)$ above the river bed (1985.11)
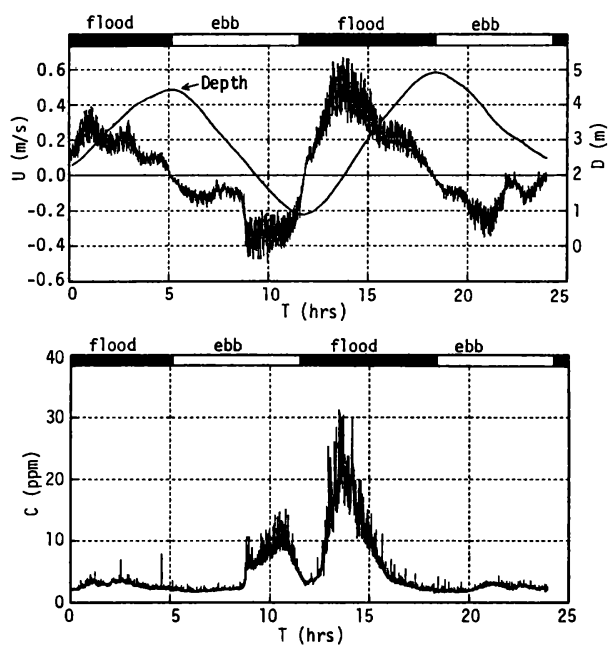

Fig. 11 Temporal variations of depth, longitudinal velocity and concentration of suspended sediment (1986.12).

$L_{c}$ の決定にあたっては，比較的底面壁に近い領域にお ける鉛直乱流場に限れば，感潮河川の乱流と大気や海洋 乱流のスケールに大きな差はないと考え, Soulsby' ${ }^{6}$ が まとめている大気乱流と海洋乱流におけるスペクトルの 測定結果を参考にした。なお，鉛直フラックスの非定常 波数スペクトルを求め, 鉛直フラックスに大きく寄与す る波数が $1 / L_{c}$ より十分大きいことを確認している.

1985 年 11 月 $25 \sim 26$ 日におけるレイノルズ応力ー $\overline{u w}$ の経時変化をFig. 10 に，1986 年 12 月 2 3 日における 主流方向流速 $(z=0.15 \mathrm{~m})$ と浮遊砂泥濃度 $(z=0.1 \mathrm{~m})$ の経時変化をFig. 11 に示す ${ }^{7)}$ (河床付近の水を採水し, 浮遊粒子の粒径を顕微鏡で観察したところ, シルト，粘 土分がほとんどであった)．2．で述べたように，平常時 放水路に流入する河川水はほとんどないから，放水路内 の濁度の上昇は大部分河床砂泥の浮上によると考えられ る、日潮不等のため, 最初の上げ潮と最後の下げ潮では 
(a)
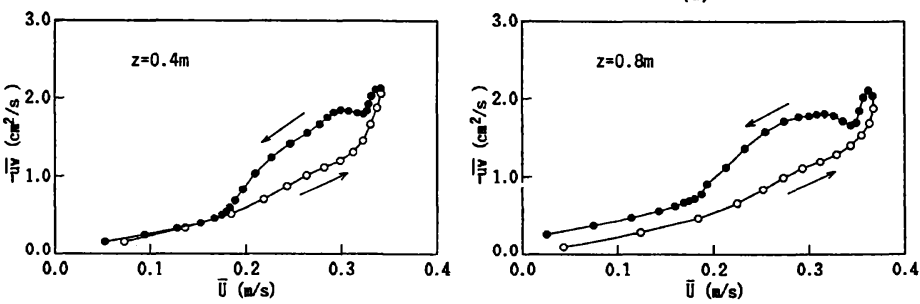

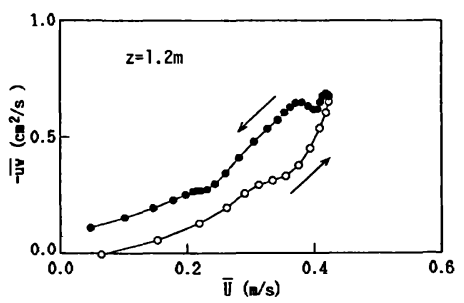

(b)

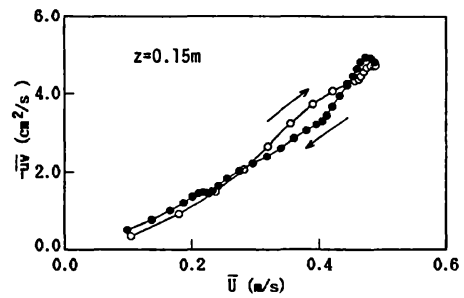

Fig. 12 Hysteresis of the Reynolds stress at four heights above the river bed. (a) flood tide (1985.11), (b) flood tide (1986.12)

平均流速が小さく, 浮遊砂泥濃度の増加はほとんどみら れない（1）で述べたように，主流方向の密度勾配に よる負の圧力勾配が深いところほよ゙大きいために，下げ 潮より上げ潮の方が河床付近の流速が大きく，レイノル ズ応力之浮遊砂泥濃度も, 上げ潮の方が下げ潮時より大 きい. $z=1.2 \mathrm{~m}$ におけるレイノルズ応力は, より河床 に近い 2 測点のレイノルズ応力よりかなり小さく，ある 程度河床から離れるとレイノルズ応力が急激に減少する ことがわかる．また，主流の向きが逆転するから，レイ ノルズ応力は，上げ潮では正，下げ潮では負となるが, $T=5 \mathrm{hrs}$ と $16 \mathrm{hrs}$ 付近では下げ潮にもかかわらず，レ イノルズ応力の符号は正となっている.これらの時刻で は平均流速が一時的に減少しており, Fig. 8 の塩分濃度 経時変化から, 主流方向の密度勾配が増大するために, 下層では圧力勾配が負となり，レイノルズ応力が正に なっているものと考えられる.

往復流の実験 ${ }^{2), 8,9)}$ や Gordon による感潮部での観 測10),11)では, 流れの加速時より減速時の方が, 乱れエネ ルギーやレイノルズ応力は大きく, 乱れエネルギー, レ イノルズ応力の最大が, 平均流速の最大より遅れるとい われている．またこれに関連して, Anwar ${ }^{12)}$ は潮流にお けるトレーサーの拡散が減速時に大きくなることを示し ている. 成層度の変化（Fig.16）が比較的少ない上げ 潮におけるレイノルズ応力の履歴をFig. 12 に示す.

Fig. 10 の 2 度目の上げ潮時におけるレイノルズ応力を 局所平均流速に対してプロットしたものがFig.12(a) で ある. ○が加速時，○が減速時を表わしている．著者ら が以前行った観測結果 ${ }^{13)}$ と同様, レイノルズ応力は加速
時より減速時の方が 2 倍程度大きいことがわかる．この ように，平均流速に対してレイノルズ応力をプロットす

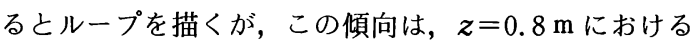
ものの方が $z=0.4 \mathrm{~m}$ の測点におけるものより強く, $z$ $=1.2 \mathrm{~m}$ では加速時初期にわずかながら負のレイノルズ 応力を示している. Fig. 12(b) は 1986 年 12 月 2 3 日 に行った河床付近 $(z=0.15 \mathrm{~m})$ の測定結果であるが, 河床に近い測点では加速時と減速時におけるレイノルズ 応力の差はほとんどみられない，なお，下げ潮では成層 度が大きく変化するため,ループを描く場合も描かない 場合もある（Fig.10のレイノルズ応力の絶対值は，2 度 目の下げ潮では上げ潮と同様, 加速時より減速時の方が 大きいが, 最初の下げ潮では加速時と減速時でほとんど 差はなかった).

濁度と流速の検出位置が一致していないので多少問題 もあるが, 高さ $0.15 \mathrm{~m}$ の位置における流速を使って, 浮遊砂泥の乱流フラックスを求めた. 乱れによる鉛直方 向の浮遊砂泥フラックスと平均浮遊砂泥濃度の関係を Fig. 12 と同様に示したのがFig. 13 である7). 図の左側 が下げ潮時，右側が上げ潮時におけるものである，上げ 潮時, 平均浮遊砂泥濃度は, 鉛直方向の乱流フラックス と同時に最大になっており，両者の間に位相差はみられ ない，これに対して，下げ潮時には，平均浮遊砂泥濃度 の最大は, 鉛直乱流フラックスの最大より遅れて生じて おり，河床砂泥の浮上よりもむしろ，上流からの移流に よって濃度が上昇していると考えられる。

次に, 上げ潮時の平均流速に対して, 平均浮遊砂泥濃 度をプロットしたものがFig. 14, 浮遊砂泥の鉛直乱流 フラックスをプロットしたものがFig. 15 である7). 平均
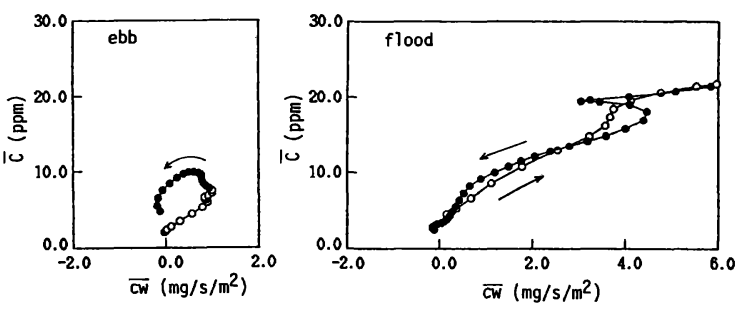

Fig. 13 Hysteresis of mean concentration of suspended sediment with vertical sediment flux (1986.12). 


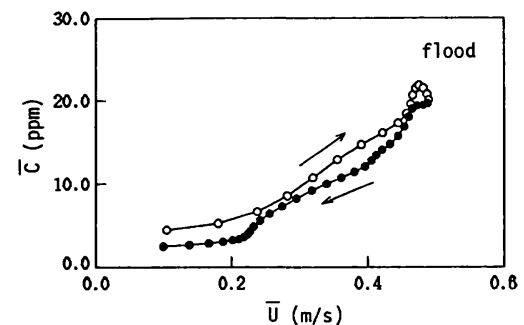

Fig. 14 Hysteresis of mean concentration of suspended sediment (1986.12).

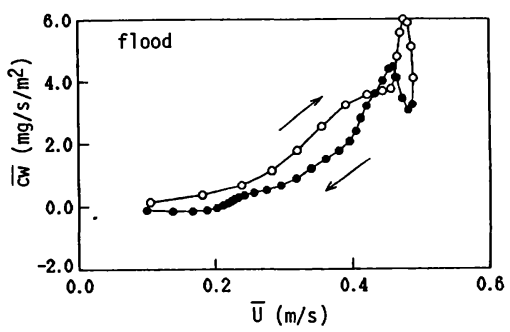

Fig. 15 Hysteresis of vertical sediment flux (1986.12).

濃度，鉛直乱流フラックスとも減速時より加速時の方が 大きく, Fig.12 のレイノルズ応力の履歴とは逆の履歴 を示している. McLean ${ }^{14)}$ も潮流中で同様な結果を得て おり，これは加速時より減速時の方が乱れが強く，河床 堆積物の浮上も減速時に活発になるとするGordonの予 想 ${ }^{11}$ に反する結果である. Levelle ら ${ }^{15}$ は底面から離れ た場所ではレイノルズ応力の最大が平均流速の最大より 遅れるものの, 底面では逆に平均流速の最大より進んで いるためにこのような結果になると説明している.

Fig. 12 に示したレイノルズ応力の履歴からわかるよう に，河床に近づくにつれて加速時と減速時におけるレイ ノルズ応力の差は小さくなっており，河床面では Levelle ら ${ }^{15)}$ のいうように平均流速より底面応力の方が 位相が進んでいる可能性もある．なお下げ潮時，鉛直乱 流フラックスは平均流速とほとんど同時に最大になる が，上げ潮時と同様，減速時より加速時の方がフラック スは大きい?).

\section{（3）潮汐に伴う鉛直成層度の变化と乱流構造}

乱れエネルギーの生成における，浮力のシア一生成率 に相対的な役割を表わすフラックス・リチャードソン数

$$
R_{f}=\frac{\frac{g}{\rho} \overline{\rho w}}{-\overline{u w} \frac{\partial \bar{U}}{\partial z}}
$$

$R_{f}$ の経時変化をFig. 16 に示す．ただし，1985 年 11 月 25 26日, 高さ $0.8 \mathrm{~m}$ の測点におけるもので, シアー 生成率一 $\overline{u w}(\partial \bar{U} / \partial z)$ が小さいとき $\left(0.005 \mathrm{~cm}^{2} / \mathrm{s}^{3}\right.$ 以 下）は除いてある. 浮カフラックスは塩分濃度と密度の

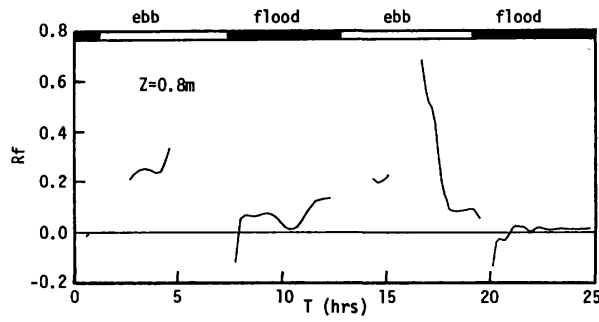

Fig. 16 Temporal variation of the flux Richardson number at height of $0.8 \mathrm{~m}$ above the river bed (1985.11).
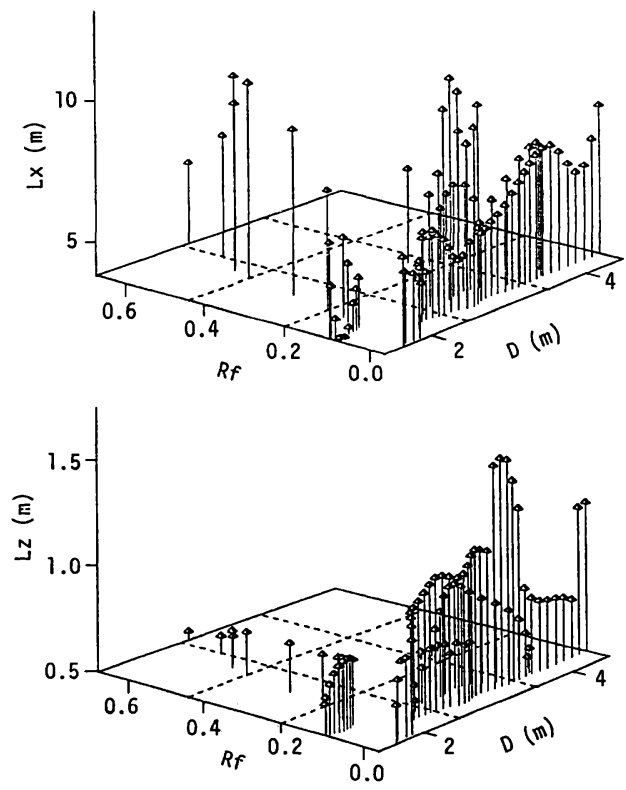

Fig. 17 Evolution of longitudinal and vertical integral length scale $L_{x}, L_{z}$ at height of $0.8 \mathrm{~m}$ above the river bed (1985.11).

関係, $\rho=\rho_{0}(1+\beta s), \beta=7.8 \times 10^{-4}(\%)^{-1}$ を使って塩分 濃度の鉛直フラックスから求め, 速度勾配 $\partial \bar{U} / \partial z$ は 4 測点の局所平均流速を 3 次スプライン関数で補間して 求めた．前回の観測結果 ${ }^{16)}$ と同様， $R_{f}$ は下げ潮時に大 きくなり，安定成層度が強くなっていることがわかる。 また，上げ潮初期には，鈶直方向の塩分濃度勾配の逆転 に対応して， $R_{f}$ は負の值を示している，下げ潮時にお ける安定成層化は主流方向の密度勾配と相まって, 2 . （1）で述べたような直線的な流速分布を形成するもの と考えられる.

次に，高さ $0.8 \mathrm{~m}$ の測点について，乱れの空間スケー ルと鉛直方向の渦動粘性係数に対する，水深と平均流速 および鉛直成層度の影響をみてみる，Fig.17は，主流 方向と鉛直方向の乱れの積分スケール $L_{x}, L_{z}$ を水深 $D$ とフラックス・リチャードソン数 $R_{f}$ に対してプロット したものである，ただし， $L_{x}, L_{z}$ は平均流速が小さい 


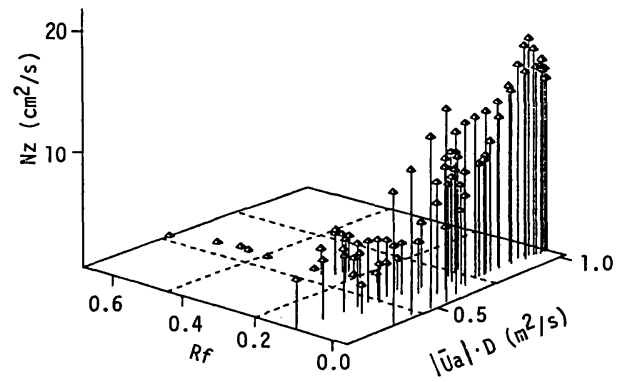

Fig. 18 Evolution of vertical eddy viscosity at height of $0.8 \mathrm{~m}$ above the river bed (1985.11).

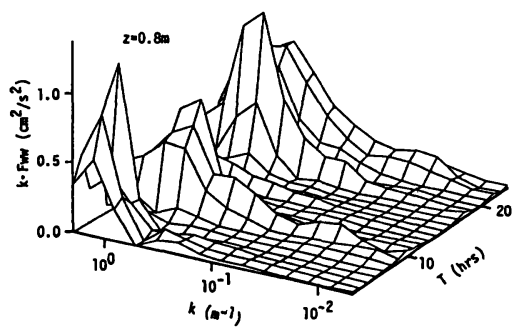

Fig. 19 Nonstationary spectrum of $w$ at height of $0.8 \mathrm{~m}$ above the river bed $(1985.11)$.

ときは除き, 主流方向, 鉛直方向の乱れ速度の相関係数 を積分して求めた。フラックス・リチャードソン数が大 きいものを除けば，主流方向の積分スケール $L_{x}$ には水 深とともにやや大きくなる傾向がみられるものの，鉛直 方向の積分スケール $L_{z}$ にはこのような傾向はみられ ず, Fig.3からわかるように, 最大平均流速付近で $L_{z}$ は最も大きくなっている．また $R_{f}$ が大きいと $L_{z}$ が小 さくなるのに対し， $L_{x}$ はかなり大きな值を示している.

鉛直方向の渦動粘性係数 $N_{z}$ を, $\left|\bar{U}_{a}\right| D$ と $R_{f}$ に対し てプロットしたものをFig. 18 に示す. $N_{z}$ は定義式から 直接求めた。 中立状態に近いときには, $\left|\bar{U}_{a}\right| D$ に比例 して $N_{z}$ は大きくなっているが, 安定成層度が強くなる と， $N_{z}$ は非常に小さくなっているのがわかる.

移流距離系列に変換した流速データをバンドパス・ フィルターに通し，その出力を 2 乗検波して非定常波数 スペクトルを求めた．成層度の影響を強く受ける鉛直方 向乱れの非定常波数スペクトルをFig. 19 に示す.ただ し, 高さ $0.8 \mathrm{~m}$ におけるもので, 縦軸はスペクトル密 度に波数を乗じたものである. 波数は $1 /$ 波長で $2 \pi$ は かかっていない，安定成層度の強くなる下げ潮時，高波 数部にエネルギーは集中し，低波数部のエネルギーは小 さい. 大規模な乱れは浮力に抗して仕事をするのに多く のエネルギーを消費するため, 安定成層度が強くなって いる下げ潮時, 大きな鉛直方向乱れは存在できなくなる ことがわかる.

\section{4. 河川感潮部における乱流輸送"17}

乱流境界層における最近の研究 ${ }^{18), 19)}$ や著者らの観測 ${ }^{16)}$ から ejection は全くランダムに発生するのではなく， 接近した ejection の集合が存在することが明らかにな り (ejection の発生確率分布は指数分布からずれ, 形状 母数が 1 より小さなガンマ分布で近似される), またさ らに, Head and Bandyopadhyay ${ }^{20)}$ や宇民・上野 ${ }^{21)}$ は乱 流境界層の大規模構造（乱流境界層の縦断面を可視化し たときにみられる大規模凸構造）が細長く引き伸ばされ たへアピン渦の集合から成ることを指摘している. ejection が大規模構造中に存在するへアピン渦によって 引き起こされると考えれば，接近した ejection の集合 が大規模乱流に対応することになる（大規模構造に含ま れる微細構造が小規模乱流に対応し, ejectionもそのな かに含まれる). Bogard and Tiederman ${ }^{18)}$ はこの接近し た ejection の集合を 1 つにまとめることによって burst を検出する方法を提案し, 検出された burst が可視化に より観測されるものと一致することを示している. そこ で, 本章では, Bogard and Tiederman ${ }^{18)}$ の方法により 同一の大規模乱流に属する ejection の最大発生時間間 隔を求め,これを時定数にもつフィルターによって乱れ を大規模な組織成分（下添字 $C$ をつけて表わす）と小 規模成分（下添字 $I$ をつけて表わす）に分離し，それ ぞれの成分が乱流輸送に果たす役割について検討する.

\section{（1）運動量と乱れエネルギーの輸送}

1985 年 11 月 25 26日におけるレイノルズ応力の経時 変化をFig. 20 に, 乱れエネルギーのシアー生成率の経 時変化をFig. 21 に示す.Fig. 20 は上から順に，大規模 乱流によるレイノルズ応力ー $\overline{u_{c} w_{c}}$ ，小規模乱流による
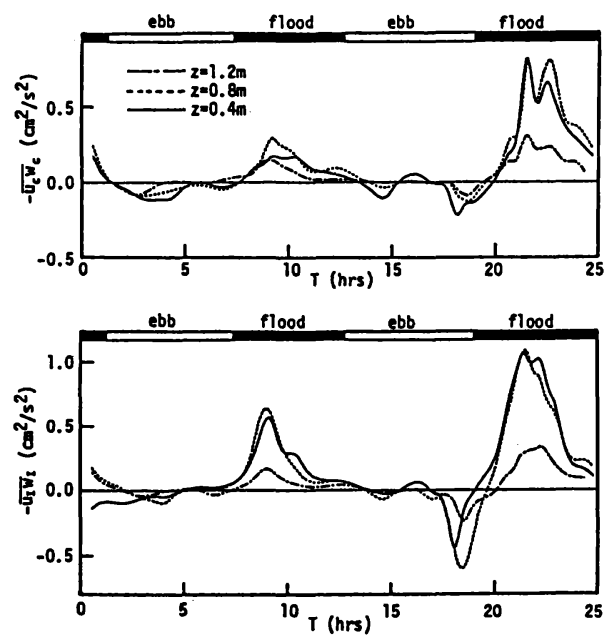

Fig. 20 Temporal variations of the Reynolds stress by largescale coherent and by small-scale turbulence (1985.11) 

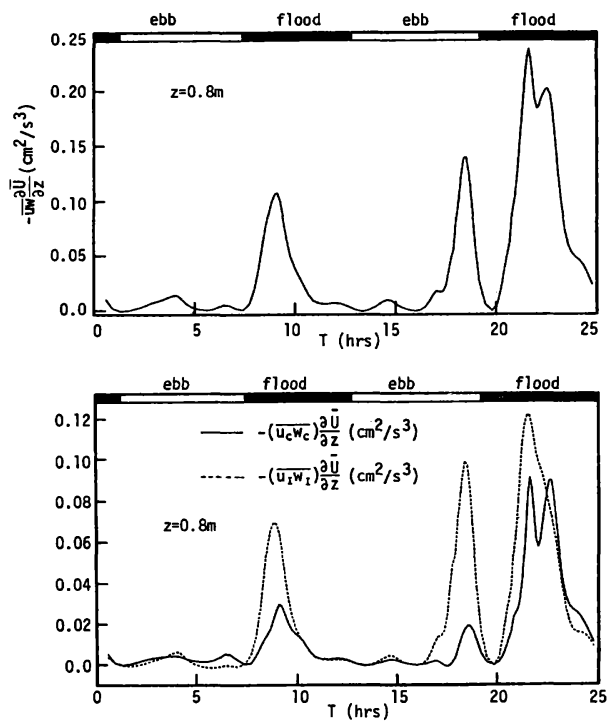

Fig. 21 Temporal variations of energy fluxes between mean, large-scale coherent, small-scale turbulent fields (1985.11).
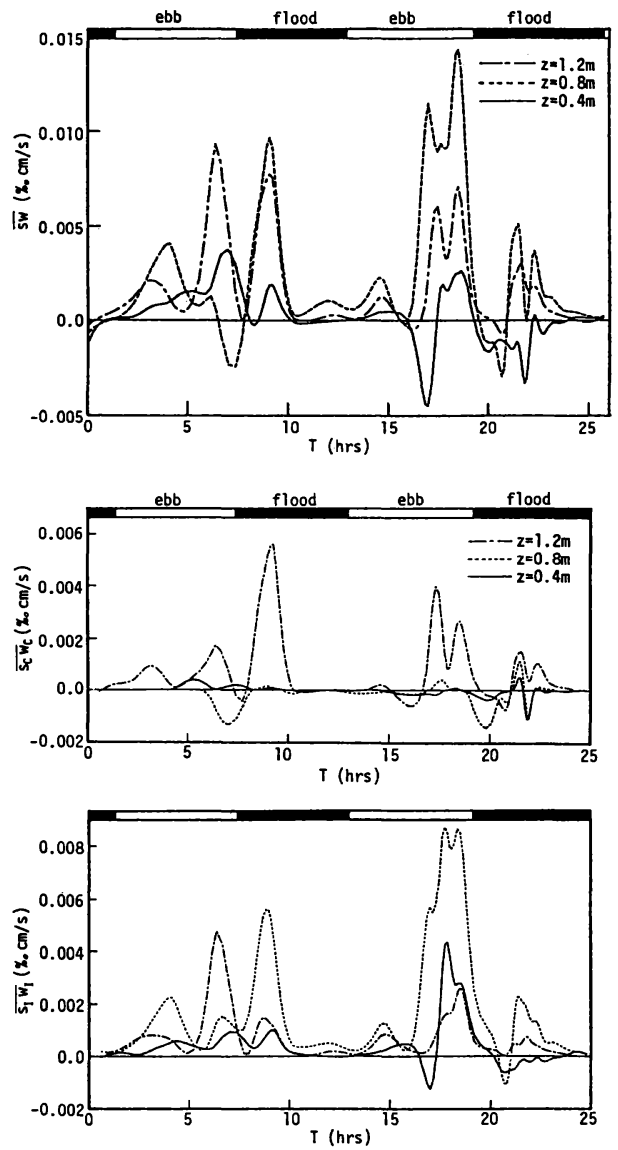

Fig. 22 Temporal variations of vertical salinity fluxes by large-scale coherent motion and by small-scale turbulence (1985.11)
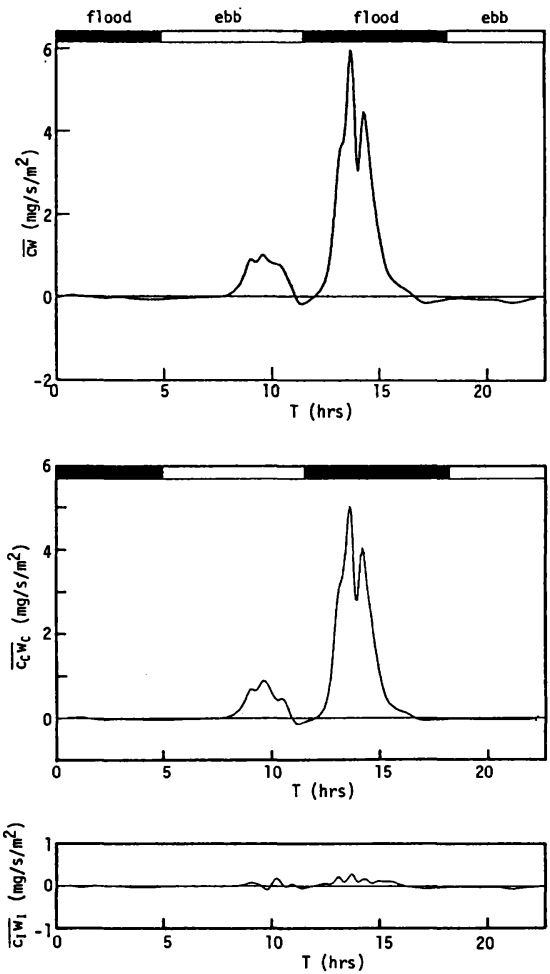

Fig. 23 Temporal variations of vertical sediment fluxes by large-scale coherent motion and by small-scale turbulence (1986.12).

レイノルズ応力ー $\overline{u_{I} w_{l}}$ の経時変化を示したものである (乱れ全体によるレイノルズ応力ー $\overline{u w}$ はFig. 10 に示し てある)。一- $\overline{u_{c} w_{c}}$ と一 $\overline{u_{l} w_{l}}$ を比べると, 両者は潮汐と ともにほぼ同様に変化しているが，一研原の方がやや 大きく, 運動量の輸送を考えるうえで, 小規模乱流も大 規模乱流と同様, 重要な役割を演ずることがわかる. Hussain ${ }^{22)}$ は, 完全に発達した乱流では, 乱流現象にお ける小規模乱流の役割が無視できず，大規模な組織乱流 と同程度の働きをすることを指摘している.

次に, 高さ $0.8 \mathrm{~m}$ におけるシアー生成率の経時変化 を示したFig. 21 をみると, 安定成層化が進んでいる 2 度目の下げ潮時には $-\overline{u_{c} w_{c}}(\partial U / \partial z)$ より $-\overline{u_{I} w_{I}}$ $(\partial U / \partial z)$ の方がずっと大きく, 平均流から乱れに輸送 されるエネルギー (Fig.21 の上段) の大部分は小規模 乱流に輸送されている．このことから，安定成層状態が 強くなる下げ潮時には，大規模な乱れは形成されにくい ことがわかる.

\section{（2）塩分濃度と河床砂泥の輸送}

1985 年 11 月 $25 \sim 26$ 日における大規模乱流と小規模 乱流による塩分濃度の鉛直フラックス $\overline{s_{c} w_{c}}, \overline{s_{I} w_{I}}$ の経 時変化をFig. 22 に示す. Fig. 22 の最上段には, 乱れ全 .体による鉛直塩分濃度フラックス $\overline{s w}$ も示してある．高 
さ $1.2 \mathrm{~m}$ の測点を除けば，小規模乱流による塩分濃度 フラックスの方が大規模乱流による塩分濃度フラックス よりずっと大きい，これは，浮力により大規模な乱れの 形成が抑えられる安定成層度の強い時間に塩分濃度の鉛 直フラックスが大きくなっているためと考えられる.

次に，大規模乱流と小規模乱流に上る浮遊砂泥の鉛直 フラックス $\overline{c_{c} w_{c}}, \overline{c_{l} w_{I}}$ の経時変化を, 乱れ全体による 浮遊砂泥の鉛直フラックス $\overline{c w}$ の経時変化とともに Fig. 23 に示す ${ }^{7)}$. Fig. 23 をみる ，小規模乱流による

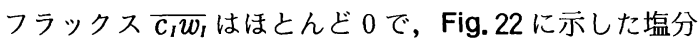
濃度の乱流フラックスとは対照的に, 浮遊砂泥の鉛直方 向への輸送は，ほとんど大規模乱流によって行われてい ることがわかる。

\section{5. 結 論}

河川感潮部における非定常乱流構造の実態を把握する ため, 太田川放水路において潮汐 2 周期にわたる流速と 塩分濃度, 濁度の同時連続測定を行った。得られた結果 を要約すると以下のようである.

（1）平均流速の鉛直分布は密度勾配のために，上げ 潮と下げ潮とではかなり異なることが明らかになった。 すなわち，下げ潮では上げ潮に比べて，上層の流速が大 きく下層の流速が小さい直線的な分布を示した.

（2）平均塩分濃度の経時変化は正弦的ではなく，干 潮の前後で大きく変化し ( 3 時間で $10 \% 0$ 程度), 満潮付 近ではほぼ一定の濃度を示した。また，下げ潮時，塩分 濃度は水面付近から低下するのに対して, 上げ潮の塩分 濃度増加時には，等濃度線はほぼ鉛直で，鉛直方向の濃 度差はほとんどみられなかった。

（3）レイノルズ応力は, 河床から離れた測点 $(z=$ $0.4 \sim 1.2 \mathrm{~m})$ では, 流れの加速時より減速時の方が 2 倍程度大きいが, 河床近く $(z=0.15 \mathrm{~m})$ では加速時と 減速時でほとんど差はみられなかった。

（4）平均流速が大きく乱れの強い上げ潮時は，下げ 潮時に比へ, 平均浮遊砂泥濃度では 2 倍, 浮遊砂泥の鉛 直乱流フラックスでは 6 倍程度の大きさを示した。

（5）平均浮遊砂泥濃度と浮遊砂泥の鉛直乱流フラッ クスは流れの減速時より加速時の方が大きく, レイノル ズ応力の履歴とは逆の履歴を示した.

（6）鉛直方向乱れ速度の積分スケールは成層化の影 響を強く受け, 水深変化の影響はあまり受けないことが 明らかになった。

（7）下げ潮時には安定成層度が強くなり,その結果, 鉛直方向の乱れは小規模なもののみとなることが明らか になった.フラックス・リチャードソン数は潮汐ととも に大きく変化し, 河床から $0.8 \mathrm{~m}$ の高さで, -0.1 0.7 程度の値を示した.
（8）鉛直方向の渦動粘性係数は平均流速と水深の変 化とともに, 成層化の影響を受けて大きく変化し, 河床 から $0.8 \mathrm{~m}$ の高さで $0 \sim 20 \mathrm{~cm}^{2} / \mathrm{s}$ 程度の大きさであっ た.

（9）小規模乱流も大規模乱流と同様, 運動量とエネ ルギーの輸送を考えるうえで重要な役割を演じている. 特に, 安定成層度が強い場合, 平均流から供給される乱 れエネルギーの大部分は小規模乱流に輸送され, 運動量 と塩分濃度の鉛直輸送の大半は, 小規模乱流によって行 われていることが明らかになった．また，鈶直方向への 浮遊砂泥の乱流輸送は, 塩分濃度の乱流輸送とは対照的 に，ほとんど大規模乱流によって行われていることが明 らかになった。

\section{参 考 文 献}

1) Nicholas, V. M. O and Rodger, J. G. : Vertical mixing in stratified tidal flows, J. Hydr. Div. Proc. ASCE, Vol. 104, No. HY 3, pp. 337 351, 1978.

2）林 泰造 - 大橋正和: 往復流境界層の乱流構造, ながれ, Vol. 1, No. 2, pp.197 207, 1982.

3) Harleman, D. R. F. and Thatcher, M. L. : Longitudinal dispersion and unsteady salinity intrusion in estuaries, LA HOUILLE BLANCHE, No. 1/2, pp. 25 33, 1974.

4) Rotta, J. C. (大路道雄訳) : 乱流, 岩波書店, pp. 138 139, 1975.

5）山口睦美・吉川 昭：非定常移流速度場におけるTaylor の凍結乱流仮説の適用と大動脈乱流のスペクトル解析へ の応用, ながれ, 3-2, pp.151〜159, 1984.

6) Soulsby, R. L. : Similarity scaling of turbulence spectra in marine and atmospheric boundary layers, J. Phys. Oceanography. Vol. 7, pp. 934 937, 1977.

7）川西 澄・余越正一郎：太田川感潮部における浮遊砂泥 と組織乱流, 第 32 回水理講演会論文集, pp. 215 220, 1988.

8) Anwar, H. O. and Atkins, R. : Turbulence measurements in simulated tidal flow, J. Hydr. Div. Proc. ASCE, Vol. 106, No. HY 8, pp. 1273 1289, 1980.

9) Hino, M. et al. : Experiments on the turbulence statistics and the structure of a reciprocating oscillatory flow, J. Fluid Mech., Vol. 131, pp. 363 399, 1983.

10) Gordon, C. M. and Dohne, C. F. : Some observations of turbulent flow in a tidal estuary, J. Geophys. Res., Vol. 78, No. 12, pp. 1971 1978, 1973.

11) Gordon, C. M. : Sediment entrainment and suspension in a turbulent tidal flow, Marine Geology, Vol.18, pp. M58 M64, 1975.

12) Anwar, H. O. : Turbulent dispersion and meandering of a surface plume, Proc. Sixteenth Congress Int. H. R. S. : Vol. 1, pp. $367 \sim 376,1975$.

13）川西 澄・余越正一郎: 太田川河口部の非定常乱流構造, 第 29 回水理講演会論文集, pp. 845 850, 1985.

14) McLean, S. R. : Turbulence and sediment transport 
measurements in a North Sea tidal inlet (The Jade), in North Sea Dynamics, Springer-Verlag, Berlin, pp. 436 452, 1983.

15) Lavelle, J. W. and Mofjeld, H. O. : Effects of timevaring viscosity on Oscillatory turbulent channel flow, J. Geophys. Res., Vol. 88, No. C12, pp. 7607 7616, 1983.

16）川西 澄・余越正一郎：河川感潮部の組織乱流, 広島大 学工学部研究報告, Vol. 35, No. 1, pp. 119 129, 1986.

17）川西 澄・余越正一郎：河川感潮部における運動量と工 ネルギーの輸送, 広島大学工学部研究報告, Vol. 36, No.1, pp. 69 75, 1987.

18) Bogard, D. G. and Tiederman, W. G. : Burst detection with single-point velocity measurements, J. Fluid Mech., Vol.162, pp. 389 413, 1986.
19) Talmon, A. M., Kunen, J. M. G. and Ooms, G. : Simultaneous flow visualization and Reynolds-stress measurement in a turbulent boundary layer, J. Fluid Mech., Vol.163, pp.459 478, 1986.

20) Head, M. R. and Bandyopadhyay, P. : New aspects of turbulent boundary layer structure, J. Fluid Mech., Vol. 107, pp. $297 \sim 338,1981$.

21）宇民 正・上野鉄雄：開水路乱流の組織的構造に関する 実験的研究, 京都大学防災研究所年報, 第 29 号 B-2, pp. 595 625, 1986.

22) Hussain, A. K. M. F. : Coherent structures and turbulence, J. Fluid Mech., Vol.173, pp. 303 356, 1986.

(1988.6.16 - 受付) 